\title{
Geochemical evidence for mantle lithosphere heterogeneity of Siberian craton.
}

\author{
Igor V. Ashchepkov ${ }^{1}$, Nikolai P. Pokhilenko ${ }^{1}$, Nikolai V. Vladykin ${ }^{2}$, Alla M. Logvinova ${ }^{1}$, \\ Valentin P. Afanasiev ${ }^{1}$, Lyudmila N. Pokhilenko ${ }^{1}$, Sergei I. Kostrovitsky ${ }^{2}$, Sergei S. \\ Kuligin', Yury B. Stegnitsky ${ }^{3}$, Anatoly Y. Rotman ${ }^{3}$, Mikhail A. Karpenko, Sergei I. \\ Mityukhin, Stanislav V. Palessky and ElenaV.Vishnyakova ${ }^{4}$ \\ ${ }^{1}$ Institute of Geology and Mineralogy SD RAS, Novosibirsk, Russia \\ ${ }^{2}$ Institute of Geochemistry SD RAS, Irkutsk \\ ${ }^{3}$ Central Scentific Research Geological Prospecting Institute, ALROSA Co Ltd, Mirny, Russia, \\ ${ }^{4}$ Novokuznetsk Metallurgical Factory, Novokuznetsk, Russia
}

Comparison of the geochemical features of mantle minerals analyzed by LAM ICP MS in IGM SB RAS ( $~ 800$ analyses for 32 elements) from mantle xenoliths and heavy concentrates (HC) reveals high scale lateral and vertical variations of mantle lithosphere beneath Yakutian kimberlite province which support the general variations oft he major components typical fro the individual pipes and kimberlite fields (Sobolev, 1997).

Lithospheric mantle rocks beneath the Daldyn and especially Alakite regions are highly depleted in modal composition and reveal high $\mathrm{La} / \mathrm{Yb}_{\mathrm{n}}$ for clinopyroxene and garnet parental melts, rising with the calculated depth (Ashchepkov et al., 2008). The most depleted minerals often keeps the signatures of the subduction origin (peaks $\mathrm{Pb}, \mathrm{U}, \mathrm{Sr}, \mathrm{Ba}$ ) (Manning, 2004), more pronounced for garnets and orthopyroxenes, while clinopyroxens are sometimes in a partial equilibrium with the other minerals and seems to be formed at the later stages due to fertilization. For peridotite clinopyroxenes from Udachnaya, Dalnyaya, Festivalnaya, Ukrainskaya the degree of the enrichment of is higher in the upper part of mantle column and in the lithosphere base and LILE and HFSE depletion vary in high scale for minerals from eclogites and pyroxenites. The REE for dunites -harzburgites (Pokhilenko et al., 1993) show U-shaped type and U$\mathrm{Pb}$ peaks are much higher.

In mantle beneath the Alakite region the regular series of the REE and TRE spectrums are individual in every mantle columns beneath the large pipes (Aykhal, Komsomol'skaya, Yubileinaya, Sytykanskaya) suggesting a pervasive metasomatism and melt percolations. They show Gar/Cpx variations in source and melting degrees (f). The most inclined spectrums are detected from the lower part of mantle sections, the very low $\mathrm{f}$ are typical for the fluid growth. For the pyroxenes from shallow and middle part of mantle sequences the $\mathrm{La} / \mathrm{Sm}, \mathrm{La} / \mathrm{Ce}_{\mathrm{n}}<1$ и $\mathrm{La} / \mathrm{Yb}_{\mathrm{n}}=10-50$, are evidencing for close to primitive parental melts (basalts and kimberlites), the inflections and U-shape depression are formed by the melt percolation (Navon, Stolper,1987) and AFC processes (De Paolo, 1981).

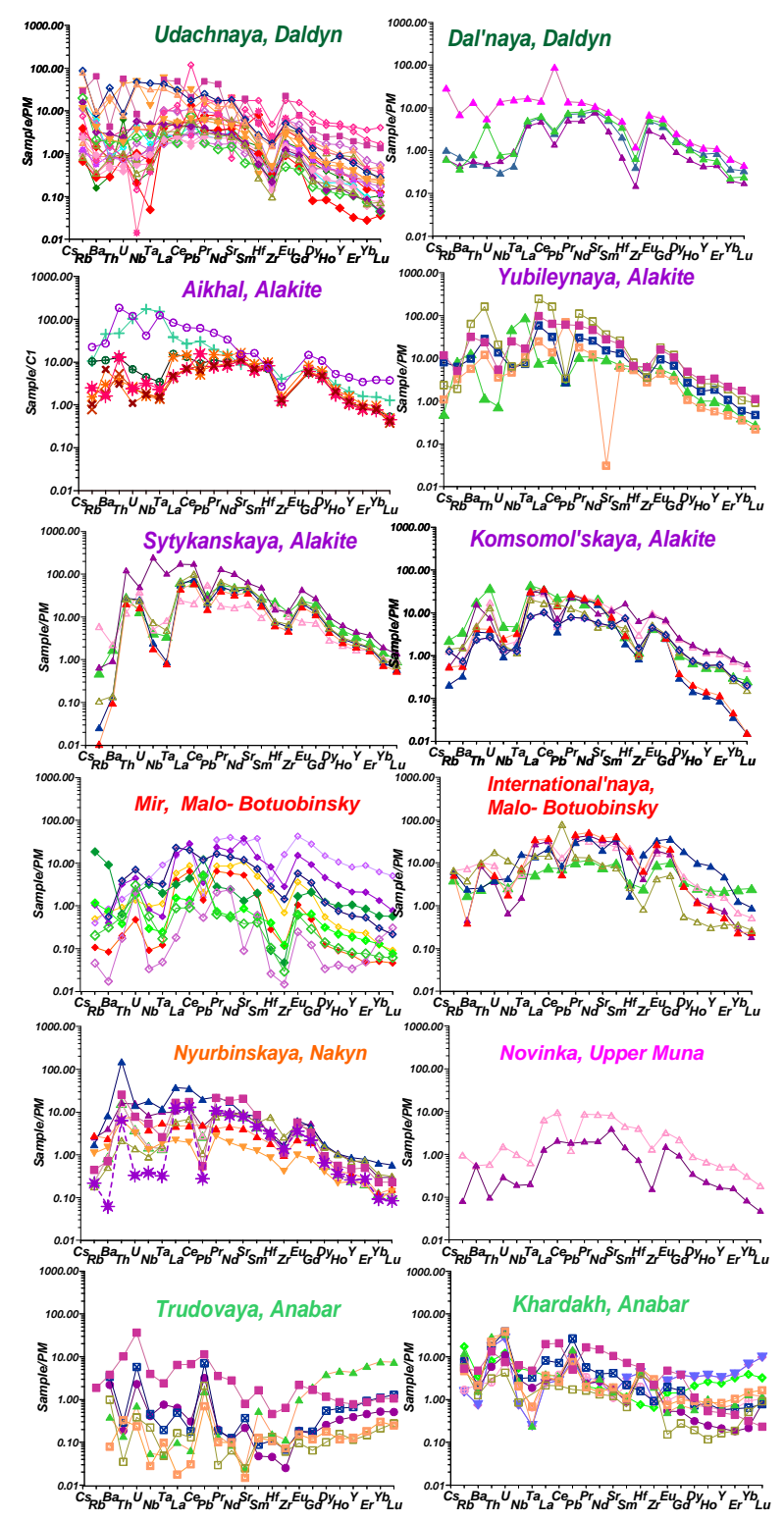

Fig.1. Trace element patterns fro the clinopyroxenes from the mantle rocks of Yakutian kimberlites 


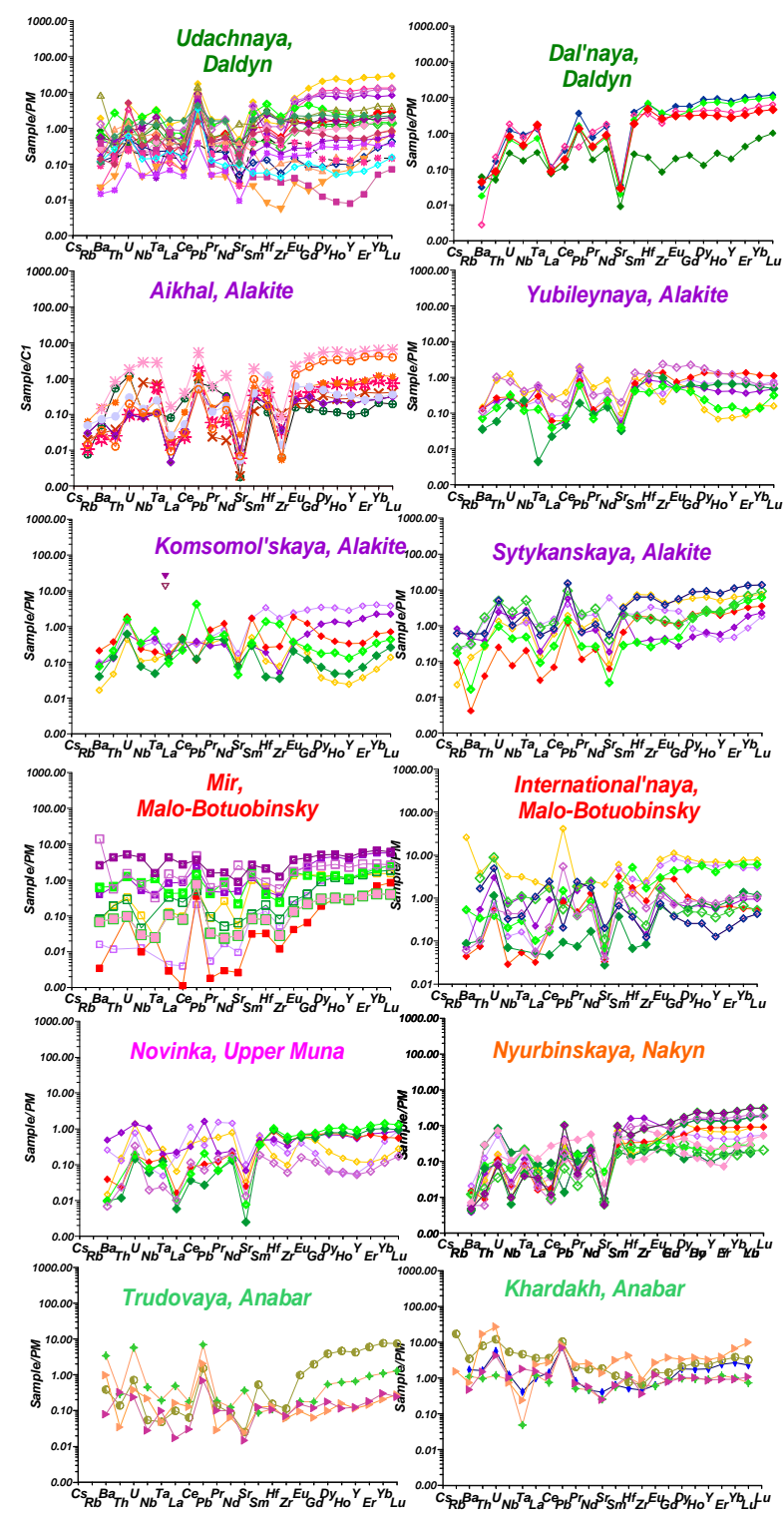

Fig.2. Trace element patterns fro the garnets from the mantle rocks of Yakutian kimberlites

Difference between upper and lower part appear at 40 kbar (pyroxenite lens) with appearance of $\mathrm{Ta}-\mathrm{Nb}$ enrichment. The degree of $\mathrm{Sm} / \mathrm{Ern}$ (S-curviness) for garnets rises with the depth.

For the minerals from the Upper Muna pipes the higher $\mathrm{f}$ and lower Gar/Cpx were determined. The rock often contain larger fraction of chromites typical fort the mantle columns affected to the heating. Clinopyroxenes from Upper Muna show nearly primitive REE and peaks in $\mathrm{Ba}$, while for all garnets strong $\mathrm{U}, \mathrm{Pb}$ peaks suggest the participation of subduction fluids. Unusually high enrichment on incompatible elements of clinopyroxenes from $\mathrm{Sp}$ and Gar facies brings to incline concave downward REE patterns high peaks of $\mathrm{Ba}$ and enrichment in $\mathrm{U}-\mathrm{Th}$ and HFSE.

TREE spectrums of the minerals from Molo Botuobinsky fields demonstrate the flattening of the TRE patterns of garnet's and Cpx's parental melts and increasing in the upper mantle part and lower Gar/Cpx ratios in general then those for mantle rocks from Daldyn and Alakite regions. Abundant undepleted lherzolitic sections with abundant metasomatic association are close to the South Africa peridotites (Gregoir et al., 2002-2003, Simon, 2004). But for International'naya the Eu- inflections and in LMREE showing the influence of eclogites and $U$ depression on HREE suggesting AFC percolation are typical

Peridotite xenocrysts of garnets from the Nakyn field show the subduction signs (Ce minima in REE patterns) while most of the clinopyroxenes reveal the signs more typical for primitive melts (reacted with protokimberlites). For clinopyroxenes from Nakyn region range of $\mathrm{La} / \mathrm{Yb}_{\mathrm{n}}$ is higher the peak of $\mathrm{Th}, \mathrm{U}$ and enrichment in incompatible element supposes the influence of carbonatitic melts and may admixture suggest of sediments in parental melts. For the minerals from Prianabarie minerals from the rocks of the upper part of mantle sections demonstrate the sign of high scale fluid interaction while those from the lower part the interaction with plume melts or relic subduction signs. Chromites from the different regions were crystallized in diverse rocks and environments. The most common have the flattened low REE spectrums and TRE spidergrams with the $\mathrm{Y}$ minima found for the diamond TRE spectrums or relatively high with the signs of fluid crystallization. TRE patterns of the phlogopites reveal the higher inclination the Cpx's REE patterns with the inflections, they display $\mathrm{Ba}$ and often HFSE peaks.

From from Mirninsky to Anabar fields (NNE-SSW) the general variations reflect progressive depletion of the mantle sections and increasing of amount of dunites and harzburgite proving the regularities determined using garnets (Griffin et al., 1998). Studied areas crossed the Archean terrains (Gladkoychub et al., 2007) which according to the geochemical features represent the creation oft he dominate fractions of mantle rocks in different environment. Mantle peridotites from Daldyn are closer to the abissal harzburgites -lherzolites affected tot he sillica enrichment and metasomatism in back ark environment. Alakite perodotites are affected to the continental margin phlogopite metasomatism. Similar features but in lower mantle section are found for Upper Muna field influenced also by the primitive melt fertilization.

The high scale silica melt enrichment and $\mathrm{K}$ metasomatism is typical fro the middle section beneath the M-Botuobinsky field. In Nakyn mantle the mixture and peridotites eclogites and sediments possibly represents the mantle of collision zone between oceanic and continent block. The mantle columns from Anabar in lower part demonstrate the high scale depletions close the frontal types of the subduction zones. But upper section show the fluid enrichment possibly showing the conditions of the sub - arc mantle..

Thus there are some typical features of the mantle sections that are pronounced mainly in the lower part oft he mantle section. The general division at $40 \mathrm{kbar}$ (Ashchepkov et al., 2008) reflects the inflection in the $\mathrm{Cr}_{2} \mathrm{O}_{3}-\mathrm{CaO}$ (Sobolev, 1977) is due to the appearance of high amount of pyroxenites (Pokhilenko et al., 2000) accompanied by the fertilization processes. In some 
regions like Anabar these processes are influenced by the very enriched in LILE.

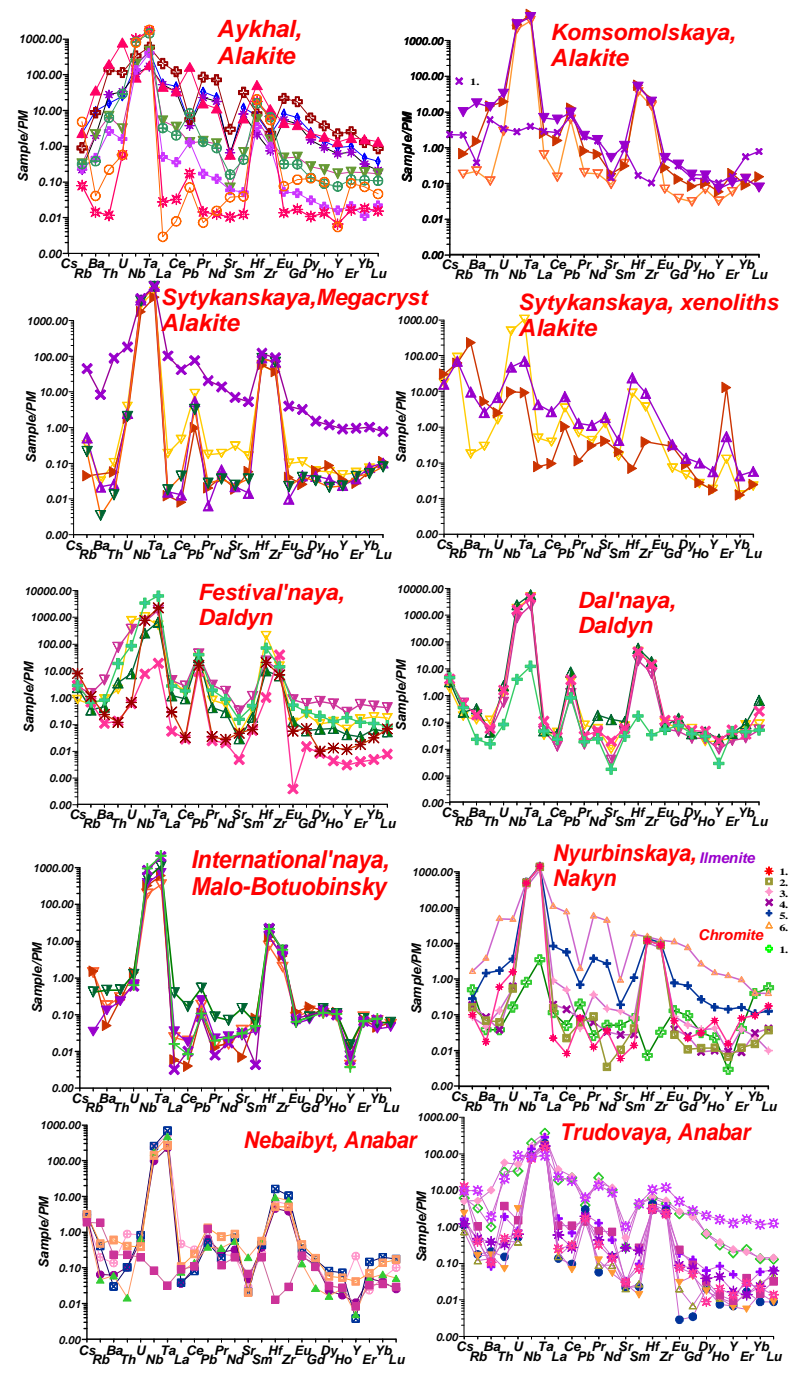

Fig.3. Trace element patterns fro the ilmenites from the mantle rocks of Yakutian kimberlites

Trace element geochemistry of the ilmenites and other megacrystalline associations show three step models. Ilmenites from each regions and pipes reveal the individual series of spectrums despite of the general similarities. High pressure metasomatites and pyroxenites have flattened REE patterns appeared in high-f melts without garnet in the source are created in the base (1). At the middle part of the mantle section they show the conform series of inclined REE spectrums typical for the protokimberlites fractionated and mixed with the partial melts from peridotites according to AFC (De Paolo, 1981) (2) and near 40 and upper in the mantle section the high TRE spectrums oversaturated in HFSE are resulted from the fluid remelting of metasomatites (3).

TRE spectrums of minerals from kimberlites evidence for the high scale multiplied melt /fluid percolation processes the initially associated with the subduction processes and growth of the craton keel and at the last stage with the interaction with the protokimberlite melts.
The influence of protokimberlite and carbonatite as well as the subduction related melts and hybridization of different scale are individual for mantle columns suggesting then they may appear as the result of the fluid flame influence in the lithospheric mantle. RFBR 05-05-74718, 06-05-65021 06-05-64416.

\section{References.}

Ashchepkov, I.V., Pokhilenko, N.P., Vladykin, N.V., Rotman A.Y., Afanasiev V.P., Logvinova A.M., Kostrovitsky S.I., Pokhilenko L.N., Karpenko M.A., Kuligin S.S., Malygina E.V., Stegnitsky Y.B., Alymova N.V. Khmelnikova O.S. 2008. Reconstruction of mantle sections beneath Yakutian kimberlite pipes using monomineral thermobarometry. Geological. Society of London (SP). 293, 335-352.

Boyd, F.R., Pokhilenko, N.P., Pearson, D.G., Mertzman, S.A., Sobolev, N.V., Finger, L.W. 1997. Composition of the Siberian cratonic mantle: evidence from Udachnaya peridotite xenoliths. Contrib. Mineral. and Petrol. 128, 228-246

De Paolo D.J. 1981. Trace element and isotopic effects of combined wall rock assimilation and fractional crystallization, Earth Planet. Sci. Lett. 53, 189-202

Gladkochub, D., Pisarevsky, S., Donskaya T., Natapov L., Mazukabzov,A., Stanevich A., Sklyarov A., 2007. The Siberian Craton and its evolution in terms of the Rodinia hypothesis. Episodes, 29, 169-173

Gregoire, M., Bell, D.R., Le Roex, A.P. 2003. Garnet lherzolites from the Kaapvaal craton (South Africa): Trace element evidence for a metasomatic history. Journal of Petrology. 44/4. 629-657.

Griffin, W. L., Ryan, C. G., Kaminsky, F. V., O’Reilly, S. Y., Natapov, L. M., Win, T. T., Kinny, P. D., Ilupin, I. P. 1999. The Siberian lithosphere traverse: Mantle terranes and the assembly of the Siberian Craton. Tectonophysics. 310, 1-35.

Manning C.E. 2004.The chemistry of subduction-zone fluids. Earth Planet .Sci. Lett . 223, 1-16

Navon O., Stolper E. 1987. Geochemical consequences of melt percolation: the upper mantle as chromatographic column. Journ.Geol., 95, 285-307.

Pokhilenko, N.P., Pearson, D.G., Boyd, F.R., Sobolev, N.V. 1991. Megacrystalline dunites: sources of Siberian diamonds. Carnegie Institute Washington Yearbook. 90, 11-18

Pokhilenko, N. P., Sobolev, N.V., Kuligin, S. S., Shimizu, N. 2000. Peculiarities of distribution of pyroxenite paragenesis garnets in Yakutian kimberlites and some aspects of the evolution of the Siberian craton lithospheric mantle. Proceedings of the VII International Kimberlite ConferenceThe P.H. Nixon volume. 690-707.

Sobolev, N.V. 1977. Deep-Seated Inclusions in Kimberlites and the Problem of the Composition of the Mantle. Amer. Geophys.Union, Washington, DC. 279. 